\title{
COVID 19 CRISIS AND PSYCHOLOGICAL WELLBEING
}

Ms. Neena Mathew*

${ }^{*} M S N$, FNP-BC, PMHNP-BC

DOI: http://doi.org/10.47211/idcij.2021.v08i01.012

\begin{abstract}
The 2019 Corona Virus Disease (COVID-19) disease (cases) first reported from China in December 2019, continues to surge through the continents affecting manycountries from Europe, America and Asia severely and is still widening its burden of disease. This infectious disease has been causing universal awareness, anxiety and distress, all of which according to WHO are natural psychological responses to the randomly changing condition.

People who are affected by COVID-19 have not done anything wrong, and they deserve our support, compassion and kindness. Protect yourself and be supportive of others. Assisting others in their time of need can benefit the helper as well as the person receiving the support. COVID-19 has affected, and is likely to affect, people from many countries and in many geographical locations. Do not attach a label of COVID-19 to any ethnicity or nationality. Be empathetic to all those who are affected, in and from any country.
\end{abstract}

Key words: Corona Virus Disease (COVID-19), psychological responses, geographical locations.

\section{ABOUT AUTHOR:}

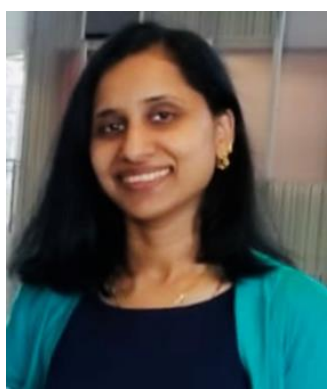

Author Ms. Mathew is a Board Certified Nurse Practitioner who is qualified to practice in both primary care and psychiatry; diagnose, treat, and prescribe medication for across the life span including children, adolescents, adults and older adults. She is currently working as a Lead Nurse Practitioner with Park Place Behavioral Healthcare, since 2016, which is a community mental health care facility in Orlando Florida. Some of her practice specialties include (but not limited to) ADHD, Depression, Anxiety and Bipolar. Mathew's style of practice can be traditional (prescribing up to date psychiatric medications) or alternative medicine (natural treatments including but not limited to vitamins, supplements, lifestyle modification, nutrition, exercise and stress management). She believes in the mind/body/spiritual connection, and we are made up as a whole person and not a series of parts, just as Hippocrates "The Father of Medicine." 


\section{ARTIC LES}

\section{CORONA VIRUS DISEASE}

The 2019 Corona Virus Disease (COVID-19) outbreak has been declared an international public health emergency on January 30, 2020 by the World Health Organization. This disease (cases) first reported from China in December 2019, continues to surge through the continents affecting many countries from Europe, America and Asia severely and is still widening its burden of disease. This infectious disease has been causing universal awareness, anxiety and distress, all of which according to WHO are natural psychological responses to the randomly changing condition.

\section{COVID 19 AND LOCKDOWN}

- Social isolation, Physical distancing and lockdown due to COVID 19 threat have affected almost every individual acrossworldwide in different ways

- Normal person having to face extraordinarysituation resulted in unique reactions

- COVID-19 has changed the order of our livesdrastically - in the blink of an eye

\section{MENTAL HEALTH}

Mental health is "a state of well-being in which the individual realizes his or her own abilities, can cope with the normal stresses of life, can work productively and fruitfully, and isable to make a contribution to his or her community"

- WHO

According to (Keyes, 2006, 2014) Mental Health

\begin{tabular}{|l|l|l|}
\hline EMOTIONALWELL-BEING & PSYCHOLOGICALWELL-BEING & SOCIAL WELL-BEING \\
\hline $\begin{array}{l}\text { Happiness, Interest in life, } \\
\text { Satisfaction }\end{array}$ & $\begin{array}{l}\text { Liking most parts of one's own } \\
\text { personality Being good at managingthe } \\
\text { responsibilities of daily life. } \\
\text { Having good relationships withothers } \\
\text { Being satisfied with one's own life. }\end{array}$ & $\begin{array}{l}\text { Positive functioning } \\
\text { Social contribution } \\
\text { Social integration } \\
\text { Social actualization - believing that } \\
\text { society is becoming a better place } \\
\text { for all people }\end{array}$ \\
\hline
\end{tabular}

Psychological well-being consists of positive relationships with others, personal mastery, autonomy, a feeling of purpose and meaningin life, and personal growth and development.

Psychological well-being is attained by achieving a state of balance affected by both challenging and rewarding life events.

Relationship between different components of Impact on psychological health COVID- 19 outbreak and Lockdown Media, news, government, financial crisis, distancing and quarantine.

Mental effects; immediate effects on mental health

irritability

fear of contracting

spreading infection to family members

anger, confusion, frustration

loneliness, denial,

anxiety, depression, insomnia,

suicide

STRESS -

Stress is common and normal for individuals to feel stressed and worried in response to any disease outbreak.

Specific stressors were:

- Rumors and misinformation (social media)

- Closure of schools and children's activity spaces

- Travel restrictions

- Physical isolation and quarantine

- Deterioration of trust in government agencies

- Avoidance of health facilities

- Risk of relapse in pre-existing health conditions

- Fear of infection (other related health problems) 
STRESSORS AND COVID 19

\begin{tabular}{|l|l|}
\hline PEOPLE & PSYCHOLOGICAL EFFECTS \\
\hline $\begin{array}{l}\text { Covid positive and quarantined } \\
\text { individuals }\end{array}$ & Anxiety, panic, loneliness, PTSD, depression \\
\hline Children & Anxiety, fear, boredom, irritability \\
\hline Health care providers & Fear, burnout, guilt, work pressure, fear of infection \\
\hline Old age & $\begin{array}{l}\text { Cognitive decline, difficulties in accessing medicine, anger, } \\
\text { fear and depression }\end{array}$ \\
\hline
\end{tabular}

\section{SOCIAL MEDIA AND MENTAL HEALTH}

As soon as covid 19 emerged to become a trending online, several users of You tube, Facebook, Whatsapp, Twitter started the business to gain popularity and thus purposefully sowed mass confusion and panic. These invite a number of overwhelming mental burdens in the form of anxiety, panic, depression, obsession, irritability, delusion of having symptoms similar to covid 19 and other paranoid ideas.

Children and Teens: Signs to Watch

$\square \quad$ Excessive crying or irritation in younger children
$\square \quad$ Returning to behaviors they have outgrown (example,bedwetting)
$\square \quad$ Excessive worry or sadness
$\square \quad$ Unhealthy eating or sleeping habits
$\square \quad$ Irritability and "acting out" behaviors in teens
$\square \quad$ Poor school performance or avoiding online classes
$\square \quad$ Difficulty with attention and concentration
$\square \quad$ Avoidance of activities enjoyed in the past
$\square \quad$ Unexplained headachesor body pain
$\square \quad$ Use of alcohol, tobacco or other drugs

WAYSTOSUPPORT

Talk with the child or teen about the COVID-19 outbreak

- Answer questions and share facts about COVID-19 in a way that the child or teen can understand

- $\quad$ Reassure the child or teen that they are safe. Let them know it is ok if they feel upset.

- $\quad$ Share with them how you deal with your own stress so that they can learn how to cope from you

- $\quad$ Limit exposure to excessive coverage of the event, including socialmedia. Children may misinterpret what they hear and can be frightened about something they do not understand

- $\quad$ Try to keep up with regular routines. If schools are closed, create a schedule for learning activities and relaxing or fun activities

- $\quad$ Be a role model. By living as an example. Take breaks, get plenty of sleep, exercise, and eat well. Connect with friends and family

\section{ROLEOFTEACHERS}

* Provide basic emotional and practical support using psychological first aid

* Help children find positive ways to express feelings such as fear and sadness

* Understand that every child has his or her own way of expressing emotions

* Sometimes engaging children in a creative activity such as playing or drawing can facilitate emotional ventilation

* Children feel relieved if they can express and communicate their feelings in a safe and supportive environment

* If children have concerns, addressing them together in the family may ease their anxiety

* andemotions for cues on how to manage their own emotions during difficult times

* Model calmness to the extent possible (Children will observe adults' behaviors)

* Avoid speculating about rumors or unverifiedinformation in front of children

ROLEOFPARENTS/CARERS

* Figure a new routine for the household and the child-collaboratively

* Remembernot to be too rigid

* Academicwork

* Householdchore 


\section{ARTIC LES}

* Interaction with peers and relativesover the phone/other technology

* Family time

* Set time for meals and bedtime

* Indoor exercise-yoga, stretches, skipping, etc

COVID AND COPING

The pandemic has led to increased stress, loneliness, anxiety and depression among people of all levels in different ways.

\section{COPING SKILLS}

Everyone has unique coping skills, some adaptive and some maladaptive, that they use to deal with stress.

\section{OVERALL WELLNESS}

Working on positive coping skills can help the individual to deal with the uncertainty of the pandemic and maintain their overall wellbeing.

Problems Need Professional Care: Seek Professional help if

- $\quad$ the behavioral and/or emotional changesaresevere

- lastformore than two weeks

- there is a significant loss of sleep or appetite

- $\quad$ thereis physical aggression towards others

- $\quad$ the adolescent expresses death wishes or suicidalideas or hopelessness or attempts self-harm

Impact on women

$$
\text { In case of any use of alcohol or other substances }
$$

- $\quad$ Differential effect on women, who provide most of informal care within families

- $\quad$ Time like this can amplify an abusive relationship andincrease intimate partner violence

- $\quad$ Home is sometimes not a safe place for all women and information should be available on access to safety, or immediate security

Impact on Pregnant Women:

- $\quad$ worries about whether or not to go for medicalexaminations

- $\quad$ worries about risks to the unborn child

- $\quad$ worries about their contact to the infection and concerns about the future

\section{How to Assure Wellbeing}

Stayconnected

- $\quad$ Try to keep personal daily routines or create new routines

- Payattention to your own needs and feelings

- $\quad$ Engage in healthy activities that you enjoy and find relaxing

- $\quad$ Exercise regularly, keep regular sleep routines and eathealthy food

- $\quad$ Limit over exposure to the near-constant stream of news and reports that cause anxiety or distress

- $\quad$ Seek information updates and practical guidance from health professionals and authentic sources

\section{Impact on Older Adults}

Avoid listening to or rumors

Older adults, especially in isolation and those with cognitivedecline/dementia, may becomemore anxious, angry, stressed, agitated and withdrawn

1. Provide practical and emotional support through informal networks (families and peers) and health professionals.

2. Share simple facts about what is going on and give clear information about how to reduce the risk of infection in words that older people with/without cognitive impairment can understand. Repeat the information whenever necessary. Instructions need to be communicated in a clear, concise, respectful and patient way.

3. Be prepared and know in advance where and how to get practical help ifneeded, such as calling a taxi, having food delivered and requesting medical care.

4. Keep regular contact with loved ones (e.g. via phone or other means). 


\section{ARTIC LES}

\section{Messages to people in isolation or quarantine}

- Try as much as possible to keep to your personal daily routines or create new ones. Engage in healthy activities that you enjoy and find relaxing. Exercise regularly, maintain regular sleep routines and eat healthy food. Keep things in perspective and use IT to connect with lovedones.

- If health authorities have recommended limiting your physical contact to contain the outbreak, you can still stay socially connected via e-mail, social media, video conferencing and telephone.

\section{Message to healthcare}

- Managing your mental health and psychosocial well-being during time is as important as managing your physical health.

- Try and use helpful coping strategies such as ensuring sufficient rest and respite during work or between shifts, eat sufficient and healthy food, engage in physical activity and stay in contact with family and friends. Avoid using unhelpful coping strategies such as tobacco, alcohol or otherdrugs. In the long term, these can worsen your mental and physical well- being.

- Turn to your colleagues, your manager or other trusted persons for social support - your colleagues may be having similar experiences toyou.

- Use understandable ways to share messages with patients with intellectual, cognitive and psychosocial disabilities.

\section{Promote work-life Balance:}

Reduce undueburden by

$>$ Identifying flexible deadlines

$>$ Helping prioritize the mostimportanttasks

$>$ Removing irrelevant tasks

$>$ When communicating with staffit is criticallyimportant to

* lead with empathy

* strivefor flexibility

* model ways to prioritize health and well-being

Message to the Public

People who are affected by COVID-19 have not done anything wrong, and they deserve our support, compassion and kindness.

To reduce stigma, do not label people as COVID-19 patients, to ensure that they are not defined by COVID-19.

Get the facts, not rumours and misinformation. To gather information at regular intervals, from and local health authorities platforms in order to help you distinguish facts from rumors. Facts can help to minimize fears.

Protect yourself and be supportive of others. Assisting others in their time of need can benefit the helper as well as the person receiving the support.

COVID-19 has affected, and is likely to affect, people from many countries and inmany geographical locations. Do not attach a label of COVID-19 to any ethnicity or nationality. Be empathetic to all those who are affected, in and from any country. 


\section{ARTIC LES}

\section{REFERENCES:}

1. Lai C, Shih T, Ko W, Tang H, Hsueh P. Severe acute respiratory syndrome coronavirus 2 (SARS-CoV-2) and coronavirus disease- 2019 (COVID-19): The epidemic and the challenges. Int J Antimicrob Agents 2020 Mar; 55(3)

2. Eurosurveillance Editorial Team. Note from the editors: World Health Organization declares novel coronavirus (2019-nCoV) sixth public health emergency of international concern. Euro Surveill 2020 Feb;25(5): 200131e

3. World Health Organization. 2020. Novel coronavirus (COVID-19) situation URL: https://covid19.who.int/ [accessed 2020-03-12]

4. Backer J, Klinkenberg D, Wallinga J. Incubation period of 2019 novel coronavirus (2019-nCoV) infections among travelers from Wuhan, China, 20-28 January 2020. Euro Surveill 2020; 25(5). [doi: 10.2807/1560-7917.es.2020.25.5.2000062]

5. World Health Organization. World Health Organization. 2020. Infection prevention and control during health care when novel coronavirus (nCoV) infection is suspected: interim guidance, January 2020 URL: https://tinyurl.com/r7w9key

6. Wang D, Hu B, Hu C, Zhu F, Liu X, Zhang J, et al. Clinical Characteristics of 138 Hospitalized Patients With 2019 Novel Coronavirus-Infected Pneumonia in Wuhan, China. JAMA. 2020.

7. Wong JEL, Leo YS, Tan CC. COVID-19 in Singapore-Current Experience: Critical Global Issues That Require Attention and Action. JAMA. 2020.

8. Brooks SK, Dunn R, Amlot R, Rubin GJ, Greenberg N. A Systematic, Thematic Review of Social and Occupational Factors Associated with Psychological Outcomes in Healthcare Employees During an Infectious Disease Outbreak. Journal of Occupational and Environmental Medicine. 2017; 60(3): 24857.

9. P. Geldsetzer. Knowledge and Perceptions of COVID-19 among the General Public in the United States and the United Kingdom: A Cross-sectional Online Survey. Annals of internal medicine. Available from: https://www.acpjournals.org/doi/10.7326/M20- 0912

10. A. S.Bhagavathula, W.Aldhaleei, Jamal R. Knowledge and Perceptions of COVID-19 among Health Care Workers: Cross- Sectional Study. JMIR Public Health Surveill. 2020 Apr-Jun; 6(2): Available from: https://www.ncbi.nlm.nih.gov/pmc/articles/PMC7193987/ 